\title{
Achieving a Campus Consensus on Learning-Centered Teaching: Process and Outcomes
}

\author{
Phyllis Blumberg \\ Justin Everett \\ University of the Sciences at Philadelphia
}

Fifty faculty and staff members attended a consensus conference on learning-centered teaching. Within small groups, participants agreed that 1) this approach develops student responsibility for their learning; 2) a consistently implemented philosophy yields a culture of learning-centered teaching, and 3) graduates of such programs become lifelong learners, self-directing, self-initiating leaders. Not all participants agreed that they could fully implement this method. They emphasized that support by administrators is a prerequisite to making changes in teaching approaches. However, the conference effectively determined levels of agreement and stimulated discussion. Results were consistent with the literature on learning-centered teaching.

\section{INTRODUCTION}

$\mathrm{D}$ uring the 2001-2002 academic year, administrators at the University of the Sciences in Philadelphia (USP) conducted a yearlong strategic planning process and identified six strategic imperatives to direct aspects of the university's planning through 2010 (USP, 2002). One of the imperatives included the development of a culcure of learning-centered teaching. According to Weimer (2002), learning-centered teaching (LCT) focuses on what students are learning, the conditions that foster learning, the students' ability to retain and apply their learning, and how well current learning facilitates future learning. When instruction is learning centered, the emphasis is on what the 
learners are doing and not what the teachers are doing. The first hurdle was to determine faculty perceptions of LCT.

To discover what the faculty thought of the concept, the director of the Teaching and Learning Center held a series of "town meetings" that all faculty were asked to attend. About half of the full-time faculty of about 150 attended at least one of these meetings. At the first forum in 2002, much confusion existed among the faculty members regarding the meaning of LCT. While some faculty members felt that they had already established a learning-centered environment in their classrooms, others felt that LCT could only occur in very small classes, and was therefore impossible at an institution where some classes are filled with several hundred students in a lecture hall. Some expressed the concern that LCT would negatively affect the content and rigor of their courses by requiring them to follow a prescribed method of delivery. They said that they did not want the content of their courses to be dumbed down because they had to utilize time-consuming teaching methods. Others simply resented LCT because they felt it interfered with their control over their own courses. It was clear that the faculty needed to be introduced to what LCT entails and how these methods could be applied in their classes without sacrificing content and rigor.

During the 2002-2003 academic year, USP began a two-pronged initiative toward creating an LCT culture. The first major initiative involved defining objectives, developing future action steps, and outlining outcome indicators. A tactical planning group (TPG) on LCT developed specific goals for this strategic imperative during the 2002 fall semester. The TPG identified the following goals for the LCT initiative.

- Faculty members, staff members, and administrators will know what LCT entails and how best to achieve it.

- The curricula will be consistent with LCT in terms of development, content, and delivery.

- Students will have the knowledge, ability, and resources to achieve responsibility and self-direction for their own learning.

- University policies, procedures, and practices will be compatible with a lcarning-centered philosophy.

At the same time, the Teaching and Learning Center (under the direction of the first author) focused on educating faculty and supporting their efforts to implement LCT. The Teaching and Learning Center hosted yearlong activities emphasizing LCT approaches, including 4 daylong workshops given by 
outside experts, 16 discussions on the topic, and a daylong event held for faculty and staff at the end of the year.

After a year of intensive work on educating and discussing LCT, the authors wanted to find out what the faculty and staff members' perceptions of LCT were, if they thought the strategies would be useful in their areas of responsibility, and how they thought the initiative could be implemented at USP. We decided to hold a consensus conference for all faculty and appropriate staff (appropriate staff members were determined to be those who worked in areas of high student interaction, such as student services).

Consensus conferences have been used in health care to help physicians and other medical personnel develop uniform practices within their various institutions and professions. Since our university has a science focus with a long history within the health sciences, it was decided that this would be a good platform for addressing LCT issues within our university. During a consensus conference, it is usual for a panel of experts to review current practices in the profession and/or institurion and make recommendations to the staff, who would then attempt to arrive at a consensus regarding uniform procedures in the areas under discussion. At USP, our experts consisted of the people who interact with our students on a daily basis-the members of our faculty and staff. Therefore, all faculty and appropriate staff and administrators were the invited experts to help reach a consensus on LCT at our institution.

In this chapter, we share our experiences with the consensus conference and describe our processes for determining faculty and staff consensus. We will also share the faculty/staff response to the conference, and offer some insight into issues that must be considered from the perspectives of faculty, staff, and administration as a small university attempts to implement a holistic LCT approach. We believe that both administration and faculty/staff members at institutions of any size will benefit from our attempts to introduce our university community to LCT. Moreover, the literature review that follows demonstrates that our findings are consistent with the literature on LCT.

\section{Setting}

Approximately 2,500 undergraduate students and 300 graduate students attended USP, all majoring in the sciences and the health sciences. Most students enter immediately after high school graduation and matriculate for four to six years depending on the length of their educational program (e.g., four years to carn a B.S., six years to earn a PharmD., or five years to earn an MPT). Moreover, the student body is very ethnically diverse. Students range from developmental and traditional freshmen to doctoral-level students. There is an 
emphasis on covering much scientific material to prepare students for their respective licensure exams.

\section{Methods of Data Collection and ANalysis}

\section{Call to Participate}

All faculty and appropriate staff and administrators were invited on multiple occasions to participate in a consensus conference. Invitations were extended in person at the faculty council meetings, through campus mail, and through email. Faculty and appropriate staff were informed of the goals of the consensus conference.

- To determine faculty and staff members' perceptions of LCT

- To discuss the usefulness of LCT in their areas of responsibility

- To discover how they thought LCT could be implemented at USP

The call to participate also stated that a position paper on LCT would be developed as a result of this conference.

\section{Description of the Process}

As the participants arrived for the half-day conference, they were asked to sit in groups of four that included others with whom they do not regularly work. Participants formed 11 groups (with a few groups of five since the exact number of participants was not divisible by four). In their groups, participants received a folder and directions for completing the summary sheets. One person in each group was asked to serve as the group facilitator and write the group's responses on their group's sheet.

Each group received a folder labeled with either a number or face card from an ordinary deck of cards. Inside the folder were several handouts describing learning-centered teaching to facilitate the discussion, including the statement from AAHE (2003) on key characteristics of learning-centered institutions, a one-page article on deep learning from the National Teaching and Learning Forum (Rhem, 1995), and two tables comparing the characteristics of LCT to traditional teaching and desirable outcome indicators that should occur with LCT compared to undesirable outcomes indicators (see Appendix 12.1); four cards each with a different suit of the number on the cover; and five copies of a summary sheet to be used for recording their consensus statements (one for each member of the group and a colored one to serve as the group summary sheet to be placed in the folder). 
Groups were asked to reach a consensus, meaning that all participants of the small group could agree with the statements they composed. If they could not reach a consensus on a certain point, they were asked not to write it down. Total agreement within the small groups was critical because the goal of the conference was to discover how faculty and staff members understood LCT, whether they thought it was possible to implement it, and if so how they thought it should be implemented. The groups were given one hour to discuss six questions, and were told that each would report to others in the following hour. Their conversations were neither recorded nor analyzed. Instead, group members recorded the results of their discussions on summary sheets. The six questions discussed were:

- What are the key elements of a learning-centered philosophy?

- What is the relationship between active learning and learning-centered teaching?

- What are the characteristics of learning-centered teaching?

- What are the characteristics of graduates of learning-centered institutions?

- How can the above be achieved in a hypothetical college?

- How can we achieve the above?

These questions allowed the participants to achieve the three goals of our study. The first two questions allowed the participants to define LCT, the third and fourth questions allowed them to consider the pros and cons of LCT, and the final question allowed them to decide how to apply the ideas at USP. Moreover, each question is more specific than the one in front of it, which allowed the participants to move from general considerations of theory to realistic ideas for implementing LCT.

After the groups had finished discussing and answering the questions on the response sheet, new groups were formed using the playing cards in each group's folder. After each person had selected a card, participants holding clubs stayed where they were and held up folders, displaying the group's number. Hearts moved up one number, the spades moved up two numbers (i.e., 10 of spades went to the queen group), and the diamonds moved down one number. This game not only broke up the monotony of the activities, but also allowed the groups to be reformed in a random fashion quickly.

The statements individuals developed in the first groups were shared with their second groups. The goal of the second small-group discussions was to 
reach a consensus from among the statements agreed upon in the original small groups. During the second hour, the groups completed and turned in another colored summary sheet of their new groups' response to the six questions. It is these responses that were eventually analyzed. While this process did not move all participants to $100 \%$ agreement on all points, it allowed everyone to consider a wide spectrum of ideas from individuals who work in parts of the university where they might normally be isolated from one another. Moreover, it allowed them to write down what they could agree on.

\section{Participants}

Fifty people representing every academic department attended, as did individuals from academic administration, student affairs, student services, and institutional advancement. At the time of the conference, USP had 152 fulltime members of the faculty, with $37 \%$ tenured, $13 \%$ tenure track, and $50 \%$ nontenure track. Participants ranged in level from instructors to deans, though most were teaching faculty ( $30 \%$ of the total full-time faculty attended).

\section{Analyses of Summary Sheets}

The summary sheets from the second groups were evaluated (independently) twice, first for general responses to the questions and second to begin conceiving broad categories for analysis. Each item noted by participants on the summary sheets was listed and counted, then broad categories were created so that the counted items could be placed in larger conceptual groups. The categories reflected common themes and concerns in higher education that were addressed by many, if not all, of the groups. The results reported here are taken directly from the data developed by these two analyses.

Item-by-item analysis. The director of the Teaching and Learning Center developed a master set of consensus statements by listing every response made by every group per question. Next she rearranged these lists to put all similar answers together and counted the similar statements. The end product of the item-by-item analysis was six response sets corresponding to the six questions with the most frequent responses noted, that is, broader inter-group consensus with the number of groups indicating such a statement, and also those that were only recorded once. The most frequent responses per question were the data that she considered further and are recorded in this chapter.

Category analysis. The second author, an English professor with a background in cooperative learning, conducted the second phase of the analysis by looking for common patterns or themes reflected in the different groups' 
answers. Each theme was reduced to a statement that, in the opinions of the researchers, reflected the spirit of each of the answers. The themes were listed underneath each of the five categories in the order of frequency. If a particular theme were mentioned in every response sheet, for example, it would appear close to the top of the list. If it was mentioned only once, it would appear closer to the bottom. This was not an attempt to list themes in order of importance, since minority opinions were considered equally important, but to reflect which items were spread across the greatest number of groups. The closer the items were to the top of the list, the more they represented a university-wide opinion.

External validation. Both analyses were shared with a committee of 10 faculty and 2 administrators to determine if they appeared to have face validity and that they emphasized the items that were actually discussed during the conference. These reviewers agreed that all of the themes listed in both data analyses fairly represented the discussion that took place at the conference. Following this, the authors summarizing the results of the consensus conference developed a position paper.

\section{RESULTS}

\section{Item-by-Item Analysis}

The following represents specific responses to each question that was recorded on the summary sheets by several groups, thus indicating broader inter-group consensus. Most of the words or phrases used here come directly from the summary sheets.

Question 1. What are the key elements of a learning-centered philosoply? All of the participants thought that LCT means helping students to develop responsibility for their own learning. Participants defined students who are learning-centered as inquisitive and self-motivating. Faculty and staff members acknowledged the roles they must play in helping students become responsible learners.

Further, participants agreed that the changes must be global. Everyone involved, from students to administrators, must understand and embrace the philosophy. All participants agreed that learning-centered approaches must be employed, with at least a portion of that dedicated to coopcrative learning techniques. From a course designer's perspective, LCT requires clearly defined course goals, outcomes, and means of assessment. Most groups indicated that it was important to consider multiple modes of delivery in order to accommodate differences in student learning styles. 
Question 2. What is the relationship between active learning and learning-centered teaching? Participants agreed that active learning is a necessary method for LCT, though some argued that this method involves presenting material in a way that captures a student's interest-including the use of traditional lectures. Responses indicated that faculty and staff members believed that LCT involves active learning, but active learning can exist on its own. Some groups summarized characteristics of either, without explaining their relationship. A few responses revealed misconceptions about the relationship between active learning and LCT as identified in the literature.

Question 3. What are the characteristics of learning-centered teaching? Responses stressed that effective instructional design is critical; the learning environment must accommodate different learning styles and various ways students learn; collaboration and teamwork are important; the instructor must spend time discussing the learning process with students; instructors must be responsive to student needs, what they know, and their level in school; instructor fexibility is important; teachers should help make students aware of their responsibilities and become actively involved in student learning; LCT can be very time-consuming; educators should serve as mentors and facilitators to their students in addition to providing information; faculty must foster academic risk-taking within safe boundaries; and there must be more extensive use of formative assessment.

Question 4. What are the characteristics of graduates of learning-centered institutions?'The respondents described students/graduates of LCT programs as lifelong learners, problem-solvers, leaders, self-directing/initiating, confident, adaptive, analytical, team oriented, effective communicators, and aware of how they learn. Such graduates will be risk-takers, lifelong learners, inquisitive, and responsible members of their professions and society.

Question 5. How can the above be achieved in a bypothetical college? All respondents emphasized that an institutional commitment is essential, and that such commitment may require a significant investment in money, training, student services, and infrastructure redesign. Faculty incentives and rewards, it was noted, must be tied in to a learning-centered approach. This philosophy needs to be adopted at all levels (students, faculty, staff, administration), but a uniform commitment on the part of the faculty and administrators is most critical of all. The college must be willing to invest in real institutional changes that go beyond merely accepting the spirit of the philosophy.

Resources must be made available during the transition phase and beyond, and could pay for faculty release time from their teaching for transforming the university from its current status to a culture of LCT. Further, the 
participants identified necessary institutional characteristics, including having small classes; a redesigned physical environment that encourages interaction; the creation of more social space; and an investment in student services as central, rather than peripheral, elements of the learning experience. All classrooms need space that is flexible with movable chairs so that interactive environments can be more easily created.

The entire university community must be willing to approach LCT with an open mind and be flexible and committed to student learning. The curriculum needs to allow for a student orientation process every year to introduce learning-centered approaches to the new students so that they will understand that they have entered an active and involved learning environment. Further, the curriculum needs to introduce real-life situations early in the educational process (i.e., internships, co-op experiences in early years) so that students will better understand the relationship between their education, their work, and the communities in which they live.

Question 6. How can we achieve the above? Participants commented that USP needs to employ mechanisms for reward and recognition to encourage a buy-in at all levels. USP's community needs to review policies and syllabi in reference to this model. Infrastructure requirements such as money, resources, small classes, environmental changes, and curricular characteristics need to be in place. Faculty and staff members will need in-service training and workshops to learn how to best utilize the LCT approach. Additionally, there needs to be a transition period for both faculty and students as we move to implement learning-centered approaches. More internships or co-op experiences would be useful. The institution must be willing to take risks and try new things. Finally, some skeptical faculty members decided that LCT may require them to alter their methods of content delivery.

\section{Category Analysis: Overall Themes}

Five themes emerged from this data, listed here from broader concerns to concepts that are more specific.

First, conceptual or theoretical issues were identified.

- The entire university community must commit to the concept for us to develop a culture of LCT.

- Commitment implies that the entire university needs to become a community of collaborative learners.

- There must be an emphasis on student responsibility for learning. 
- The classroom must also become a community of learners.

- To be adaptive to learners' varying needs, LCT must utilize different learning styles.

Second, when teaching is truly learning centered, students or graduates:

- Will be self-motivated (willing to take responsibility for their learning)

- Will demonstrate academic integrity

- Will participate in cross-disciplinary learning experiences

- Will be team players, good cooperative learners, and leaders

- Will desire to become lifelong learners

- Will assess their own learning

- Will show appreciation of differences between individuals and cultures

- Will commit to global awareness, multiculturalism, cross-disciplinary learning, and social responsibility

Third, certain curriculum or course design issues emerged. Instructors need clearly defined learning goals, objectives, and outcomes. Faculty need to:

- Recognize that the learning process is as important as the content

- Use alternative teaching methods in addition to lecture and labs

- Utilize cooperative learning experiences

- Develop critical thinking skills

- Realize that learning extends from the classroom to the community

- Accept that learning occurs in a variety of contexts, both in and out of the classroom

- Acknowledge that assessment serves multiple purposes by providing students, instructors, and administrators with valuable feedback

Fourth, faculty roles must change. Among the initiatives the participants believed would bencfit USP were:

- Prior to implementing changes, instructors need to be educated about and learn to use LCT models. 
- New and existing faculty members need orientations to these approaches.

- Professors need to act as facilitators of learning.

- Teaching styles should accommodate student learning styles.

- Instructors and students need to participate in self-assessment and program assessment.

- Faculty members need to encourage learning for its own sake.

- Teachers need to support cross-disciplinary experiences.

Finally, to achieve the above, the following changes need to occur at this university.

- The university should sponsor faculty incentive awards for innovation and participation in learning-centered teaching.

- USP needs to provide workshop opportunities for students and faculty.

- The campus needs to be redesigned to function as an LCT environment.

For example, learning spaces must be created to facilitate learning through group interaction. We need to create more classroom, lab, and student services spaces for social interaction in addition to learning space. The physical space must be uncluttered, accessible, and inviting in order to create an engaging environment that encourages students, instructors, and administrators to interact as part of a community of learners. In addition to being housed in open, redesigned spaces, student support services should be supplied with adequate staff and resources. To allow this university to function at the highest level of professor-student interaction, lecture halls would have to be replaced with spaces that are more intimate.

\section{Summary of Findings From Both Analyses}

When additional people were asked to compare the results of these two analyses to see if they showed the same themes, agreement over themes was apparent. These themes appeared on most summary statements. The consensus statement themes are summarized in Table 12.1.

Dissemination of results. The authors developed a position paper on LCT based upon the information recorded in the summary sheets and described the process used to reach these consensus statements. The dircctor of the Teaching and Learning Center met indiviciually with all vice presidents, deans, and chairs and gave each a copy of the position paper. These meetings 
TABLE 12.1

\section{Consistency of Faculty Consensus Statement Themes With the Literature on Learning-Centered Teaching}

\begin{tabular}{|c|c|c|}
\hline $\begin{array}{l}\text { USP consensus statement } \\
\text { theme }\end{array}$ & $\begin{array}{l}\text { Is this statement consistent } \\
\text { with the learning-centered } \\
\text { literature? If yes, citation is } \\
\text { given. }\end{array}$ & $\begin{array}{l}\text { How the literature expands } \\
\text { upon or clarifies the theme } \\
\text { raised by the consensus } \\
\text { conference participants }\end{array}$ \\
\hline $\begin{array}{l}\text { Learning-centered teaching } \\
\text { means developing student } \\
\text { responsibility for their own } \\
\text { learning and meaning. }\end{array}$ & $\begin{array}{l}\text { Yes: (Association of American } \\
\text { Colleges and Universities } \\
\text { [AAC\&U], 2002; AAHE, } \\
\text { 2003; Barr \& Tagg, 1995; } \\
\text { Coffman, 2002; Doherty, } \\
\text { Riordan, \& Roth, 2002; } \\
\text { Fink, 2003; Tagg, 2003; } \\
\text { Weimer, 2002) }\end{array}$ & $\begin{array}{l}\text { This theme is consistently } \\
\text { agreed upon as essential in all } \\
\text { of the literature on learning- } \\
\text { centered teaching. }\end{array}$ \\
\hline $\begin{array}{l}\text { This philosophy of an } \\
\text { emphasis on learning must be } \\
\text { accepted and implemented } \\
\text { consistently across the entire } \\
\text { university. }\end{array}$ & $\begin{array}{l}\text { Yes: (AAC\&U, 2002; } \\
\text { AAHE, 2003; } \\
\text { Doherty, et al., 2002; } \\
\text { Tagg, 2003) }\end{array}$ & $\begin{array}{l}\text { A consistency and alignment } \\
\text { of philosophy, practices, and } \\
\text { policies at all levels is needed. }\end{array}$ \\
\hline $\begin{array}{l}\text { The reward structure needs to } \\
\text { be consistent with this value. }\end{array}$ & $\begin{array}{l}\text { Yes: (AAC\&U, 2002; } \\
\text { AAHE, 2003; Barr \& Tagg, } \\
\text { 1995; Doherty et al., 2002; } \\
\text { Tagg, 2003; Weimer, 2002) }\end{array}$ & $\begin{array}{l}\text { Considerations for faculty and } \\
\text { staff remuneration increases } \\
\text { and promotions need to } \\
\text { consider how the person } \\
\text { demonstrated a focus on } \\
\text { learning. }\end{array}$ \\
\hline $\begin{array}{l}\text { Instructional design and the } \\
\text { learning environment should } \\
\text { accommodate different } \\
\text { learning styles. }\end{array}$ & $\begin{array}{l}\text { Yes: (AAC\&U, 2002; } \\
\text { Doherty, et al., 2002; } \\
\text { Fink, 2003) }\end{array}$ & $\begin{array}{l}\text { In addition to accommodating } \\
\text { learning styles, the overall goal } \\
\text { of educational programs is to } \\
\text { engage students in deep } \\
\text { learning. }\end{array}$ \\
\hline $\begin{array}{l}\text { Being lifelong, self-directed, } \\
\text { self-initiating learners and } \\
\text { leaders, and possessing } \\
\text { excellent problem-solving } \\
\text { abilities characterize } \\
\text { students/graduates of such } \\
\text { learning-centered programs. }\end{array}$ & $\begin{array}{l}\text { Yes: (AAC\&U, 2002; } \\
\text { Doherty et al., 2002; } \\
\text { Fink, 2003; Tagg, 2003; } \\
\text { Weimer, 2002) }\end{array}$ & $\begin{array}{l}\text { This theme emphasizes the } \\
\text { importance of going beyond } \\
\text { the content of a course to } \\
\text { articulate what students can } \\
\text { do as a result of their learning. }\end{array}$ \\
\hline $\begin{array}{l}\text { It is necessary to have } \\
\text { classrooms and a physical } \\
\text { environment that is conducive } \\
\text { to actively engaging students. }\end{array}$ & $\begin{array}{l}\text { Yes: (Doherty et al., 2002; } \\
\text { Tagg, 2003) }\end{array}$ & $\begin{array}{l}\text { When classtooms have } \\
\text { moveable furniture, faculty } \\
\text { can make the environment } \\
\text { meet their varied instructional } \\
\text { needs better. }\end{array}$ \\
\hline
\end{tabular}




\begin{tabular}{|l|l|l|}
\hline $\begin{array}{l}\text { It is necessary to educate and } \\
\text { orient all faculty and staff. }\end{array}$ & $\begin{array}{l}\text { Yes: (AAC\&U, 2002; Do- } \\
\text { herty, et al., 2002; Felder \& } \\
\text { Brent, 1996; Fink, 2003; Tagg, } \\
2003 ; \text { Weimer, 2002) }\end{array}$ & $\begin{array}{l}\text { Transition to a culture of } \\
\text { learning centeredness may in- } \\
\text { volve different approaches to } \\
\text { teaching and interacting with } \\
\text { students. Faculty and staff } \\
\text { need education and support } \\
\text { to be able to make the neces- } \\
\text { sary changes. }\end{array}$ \\
\hline $\begin{array}{l}\text { It is necessary to educate and } \\
\text { orient all students as to why } \\
\text { the universiry is using a learn- } \\
\text { ing-centered approach. }\end{array}$ & $\begin{array}{l}\text { Yes: (AAHE, 2003; Felder } \\
\text { and Brent, 1996) }\end{array}$ & $\begin{array}{l}\text { A stronger statement of this } \\
\text { theme would also explain and } \\
\text { explicitly document the ex- } \\
\text { pected learning outcomes. }\end{array}$ \\
\hline $\begin{array}{l}\text { It is necessary to have an infra- } \\
\text { structure and dedicated re- } \\
\text { sources to foster a culture of } \\
\text { learning-centered teaching. }\end{array}$ & $\begin{array}{l}\text { Yes: (AAC\&U, 2002; AAHE, } \\
2003 ; \text { Doherty, et. al., 2002) }\end{array}$ & $\begin{array}{l}\text { Institutions that make the } \\
\text { commitment to a culture of } \\
\text { learning-centeredness need to } \\
\text { direct resources to foster and } \\
\text { support this culture. }\end{array}$ \\
\hline $\begin{array}{l}\text { It is necessary to have support } \\
\text { and release time to encourage } \\
\text { the transition to learning-cen- } \\
\text { tered teaching. }\end{array}$ & $\begin{array}{l}\text { Yes: (AAC\&U, 2002; AAHE, } \\
2003 ; \text { Doherty, et al., 2002) }\end{array}$ & $\begin{array}{l}\text { Faculty and staff need assur- } \\
\text { ance of the institution's serious } \\
\text { commitment to this change as } \\
\text { well as help in promoting it to } \\
\text { help assure them that this is } \\
\text { not a short-lived fad. }\end{array}$ \\
\hline
\end{tabular}

provided opportunities to further discuss ways for the center to promote LCT. Moreover, the results of the consensus conference were reviewed in open forums with faculty. The director also met with the departments of public relations, institutional advancement, and admissions to discuss how they might use these findings. The position paper from the consensus conference on LCT was placed on the university's web site (www.usip.edu/teaching/learner).

\section{Discussion}

\section{Usefulness of the Process}

Good representation from all of the stakeholder constituencies is essential for the results to be valid. By helping almost one-third of our faculty work toward consensus on this issue, the conference allowed USP to establish validity and buy-in on our campus. More specifically, this process of discussion and development of a position paper was an efficient method for discovering many people's opinions and to summarize the findings on a current issue. This process also allowed for campus dialogue and learning to occur at the same time. The format of using two different small groups fostered much exchange of ideas. 
Since we did not record what actually went on in the small groups, we cannot comment on the actual processes groups used. We do not know what points were contentious or why they failed to reach a consensus on other concepts. However, faculty commented that the discussion helped them to clarify their own thinking on learning-centered approaches. Because participants had invested in the discussion process, they looked forward to the results and attended sessions on the position paper that came from the conference. We believe that at other institutions faculty developers would find this process of conducting a consensus conference and developing a position paper useful for issues where the campus is striving to make changes.

\section{Comparison With the Literature on Learning-Centered Teaching}

As shown in Table 12.1, the consensus conference statements are very consistent with the literature on LCT. The participants correctly identified the key features of programs and of graduates. They also expressed the widely held view that there needs to be a great deal of alignment and consistency across all aspects of the university. Perhaps with greater knowledge as a result of the educational events held on campus, participants were asking for more administrative support and dedicated resources. Higher education associations and national panels (e.g., AAHE, AAC\&U, \& Doherty et al.) have also stressed the importance of infrastructure, resources, and rewards to achieve these broad changes in approach. Perhaps the only area that the participants did not express the views of the literature relates to the essential roles of assessment, both formative and summative, to determine the quality of learning. The literature stresses the role of assessment in the learning process, both as feedback to the learners and to help improve the educational programs.

\section{Campus Validation}

The position paper and the results discussed in this chapter represent a snapshot of the thinking about LCT by faculty, administrators, and staff at one university. The consensus conference validates the idea that the faculty, administrators, and staff at USP are at different points in their understanding and use of LCT. Some are very new to this type of teaching, while others have been doing it for a while. The themes identified more specific comments on how the institution can create such a culture (such as changing the physical environment) and less what the professors themselves need to do to make their own teaching more learning centered. Perhaps the faculty members believe that they cannot innovate in the classroom until the administrators put in place tangible support such as release time or changes in the class size or 
environment. Others might need more assurance that this is indeed a new direction for this university and not just another academic trend. If the institution puts these supports in place, we believe that more faculty members will make changes in techniques and approaches in their own teaching. It is noteworthy that participants made fewer comments about how they will engage the students in the material in their own courses betrer, or how they will help them understand the purposes of learning more fully. Clearly, the Teaching and Learning Center can continue to focus on educating faculty and staff on ways of urilizing LCT in the classroom.

While this activity was not related to the TPG, and many more people participated in this consensus conference than the TPGs, the recommendations are consistent with and validate the recommended action steps of the TPG on LCT. Although not stated in these terms, participants affirmed the importance of the key results areas developed by the TPG. The statements made by the participants of the consensus conference indicate that these results need to be implemented to achieve a culture of LCT. Also, the list of the characteristics of learning-centered institutions and students or graduates of such programs developed by the participants of the consensus conference will be used to form a benchmark to assess our progress toward achieving these outcomes. The desired outcomes and characteristics will be used as a guide for reviewing this university's policies, procedures, and practices to see how compatible they are with a LCT philosophy. To help achieve this end, faculty can assess themselves to see if their own policies and practices are consistent with the consensus statements. Perhaps with the position paper reflecting the views of many people at USP, there will be greater impetus to work to achieve them.

\section{Conclusion}

The university administrators and the director of the Teaching and Learning Center should be very encouraged by how much this university agreed on the concepts of LCT after only one year of exposure to the concept. Many faculty and staff have a good understanding of what it is and the characteristics of graduates of such programs. Some of the concerns were similar to those raised a year earlier at the first faculty open forum (such as the perceived need for small classes and that LCT is time-consuming to develop and to implement). However, the statements made at the consensus conference also show greater insight and significant progress toward accepting this philosophy. The participants at the conference did not raise as many concerns (e.g., about reducing course content or rigor), as had been expressed previously on other occasions. Clearly, the faculty members have learned that there are alternatives to traditional lectures. 
They now know that there are many different approaches to teaching and that the administration is not forcing them to radically change their methods overnight. It is our hope that because they are not being told how to teach as much as they feared there is now a greater willingness to consider learningcentered concepts.

All participants and the general university community should be very encouraged by the level of agreement generated by this conference. From an administrative perspective, perhaps the greatest benefit of this event was the ability to generate in an afternoon a degree of consensus that might otherwise have taken years to develop through emails, phone calls, and commitree meetings. That, if nothing else, is an accomplishment.

\section{REFERENCES}

American Association for Higher Education. (2003). Resources for inquiry and action: The learning-centered institurion. Inquiry and Action, 1. Retrieved December 11, 2003, from http://orww.aahe.org/pubs/LASpring2003.pdf

Association of American Colleges and Universities. (2002). Greaser expectations: A new vision for learning as a nation goes to college. Washington, DC: Author. Retrieved June 2, 2003, from http://www.greaterexpectations.org

Barr, R. B., \& Tagg, J. (1995). From teaching to learning: A new paradigm for undergraduate education. Change, 28(2), 42-47.

Coffman, S. J. (2002). Ten strategies for getting students to take responsibility for their learning. College Teaching, 51, 2-4.

DeZure, D. (Ed.). (2000). Learning from change: Landmarks in teaching and learning in higher education from Change magazine 1969-1999. Sterling, VA: Stylus.

Doherty, A., Riordan, T., Roth, J. (Eds.). (2002). Student learning: A central focus for institutions of higher education. Milwaukee, WI: Alverno College Institute.

Felder, R. M., \& Brent, R. (1996). Navigating the bumpy road to student-centered instruction. College Teaching, 44, 43-47. Retrieved December 3, 2003, from http://www.ncsu.edu/felder-public/Papers/Resist.heml

Fink, L. D. (2003). Creating significant learning experiences: An integrated approach to designing college courses. San Francisco, CA: Jossey-Bass.

Graesser, A. C., Person, N. K., Hu, X. (2002). Improving comprehension through discourse processing. In D. F. Halpern \& M. D. Hakel (Eds.), New directions for teaching and learning: No. 89. Applying the science of learning to university teaching and beyond (pp. 33-44). San Francisco, CA: Jossey-Bass. 
Matlin, M. W. (2002). Cognitive psychology and college-level pedagogy: Two siblings that rarely communicate. In D. F. Halpern \& M. D. Hakel (Eds.), New directions for teaching and learning: No. 89. Applying the science of learning to university teaching and beyond (pp. 87-103). San Francisco, CA: Jossey-Bass.

Rhem, J. (1995). Close Up Column: Going deep. National Teaching and Learning Forum, 5(1), 4.

Sternberg, R. J., \& Grigorenko, E. L. (2002). The theory of successful intelligence as a basis for instruction and assessment in higher education. In D. F. Halpern \& M. D. Hakel (Eds.), New directions for teaching and learning: No. 89. Applying the science of learning to university teaching and beyond (pp. 45-54). San Francisco, CA: Jossey-Bass.

Tagg, J. (2003). The learning paradigm college. Bolton, MA: Anker.

University of the Sciences in Philadelphia. (2002). Tactical planning group report on creating a culture of student-centered learning and living. Philadelphia, PA: Author.

Weimer, M. (2002). Learner-centered teaching: Five key changes to practice. San Francisco, CA: Jossey-Bass. 


\section{APPENDIX 12.1}

\section{Consensus Conference Materiats}

Characteristics of Learning-Centered Teaching and Traditional Teacher-Centered Instruction

\begin{tabular}{|c|c|c|}
\hline $\begin{array}{l}\text { How does cach model } \\
\text { address these questions? }\end{array}$ & Learning-centered teaching & Faculty-centered teaching \\
\hline What drives the system? & Student-learning-driven & Instructionally driven \\
\hline \multirow[t]{2}{*}{$\begin{array}{l}\text { How are educational } \\
\text { programs planned? }\end{array}$} & $\begin{array}{l}\text { Educational objectives } \\
\text { determine instructional } \\
\text { format, varied modalities. }\end{array}$ & $\begin{array}{l}\text { Traditional, instructor-driven } \\
\text { modalities, that is, lecture, lab, } \\
\text { recitation, and discussions } \\
\text { predominate. }\end{array}$ \\
\hline & $\begin{array}{l}\text { Planned consistency among } \\
\text { objectives, teaching/learning } \\
\text { eransactions, and assessments } \\
\text { (Fink, 2003) }\end{array}$ & $\begin{array}{l}\text { Arbitrary alignment among } \\
\text { objectives, teaching/learning } \\
\text { transactions, and assessments; } \\
\text { possible inconsistencies }\end{array}$ \\
\hline \multirow[t]{2}{*}{$\begin{array}{l}\text { What are the major roles } \\
\text { for faculy?? }\end{array}$} & $\begin{array}{l}\text { Faculty become designers of } \\
\text { learning environments for } \\
\text { students (Barr \& Tagg, 1995), } \\
\text { facilitators of student active } \\
\text { learning, and model expert } \\
\text { thought processes. }\end{array}$ & $\begin{array}{l}\text { Instructor, as content expert, } \\
\text { conveys material. }\end{array}$ \\
\hline & $\begin{array}{l}\text { Faculty enable students so learn } \\
\text { effectively and efficiently in } \\
\text { varied environments. }\end{array}$ & $\begin{array}{l}\text { Faculty transmit information, } \\
\text { and may not provide enough } \\
\text { assistance for students to master } \\
\text { content. }\end{array}$ \\
\hline How is power distributed? & $\begin{array}{l}\text { Faculty control the content. } \\
\text { Power is shared with students so } \\
\text { that they can be involved in the } \\
\text { conditions of learning. This } \\
\text { balance of pouver leads to greater } \\
\text { student responsibility Weimer. } \\
\text { 2002). }\end{array}$ & $\begin{array}{l}\text { Faculty control she content, the } \\
\text { learning process, the conditions } \\
\text { for learning, and the assessments, } \\
\text { all of which lead to dependent, } \\
\text { unmotivated students (Weimer, } \\
\text { 2002). }\end{array}$ \\
\hline $\begin{array}{l}\text { What guides how } \\
\text { students are taught? }\end{array}$ & $\begin{array}{l}\text { Evidence-based research } \\
\text { (Matlin, 2002; Sternberg \& } \\
\text { Grigorenko, 2002) guides the } \\
\text { principles of the teaching/ } \\
\text { learning transactions and } \\
\text { assessments. }\end{array}$ & $\begin{array}{l}\text { Inseructors teach largely based } \\
\text { on how they were taught. }\end{array}$ \\
\hline How are students taught? & $\begin{array}{l}\text { Adaptation of teaching/ } \\
\text { learning transactions to } \\
\text { accommodate students' } \\
\text { learning styles, abilities, varied } \\
\text { needs of diverse student } \\
\text { population (DeZure, 2000) }\end{array}$ & $\begin{array}{l}\text { Instruction tends to be a one- } \\
\text { size-fits-all approach; students } \\
\text { must adapt to the system to } \\
\text { succeed. }\end{array}$ \\
\hline
\end{tabular}




\begin{tabular}{|l|l|l|}
\hline $\begin{array}{l}\text { How are students exposed } \\
\text { to new material? }\end{array}$ & $\begin{array}{l}\text { Students are directly involved } \\
\text { in the discovery of knowledge, } \\
\text { employ inquiry-based methods } \\
\text { to understand and use the } \\
\text { material (Graesser, Person, Hu, } \\
2002) ; \text { prior knowledge is } \\
\text { considered to facilitate } \\
\text { learning. }\end{array}$ & $\begin{array}{l}\text { Faculty are concerned with } \\
\text { coverage of a large amount of } \\
\text { material, possibly at the expense } \\
\text { of student understanding. }\end{array}$ \\
\hline $\begin{array}{l}\text { How do students spend } \\
\text { their time? }\end{array}$ & $\begin{array}{l}\text { Students are actively engaged in } \\
\text { theirlearning process. }\end{array}$ & $\begin{array}{l}\text { Students often are passive } \\
\text { receivers of information. }\end{array}$ \\
\hline How do students study? & $\begin{array}{l}\text { Engaged students foster deep } \\
\text { learning (material integrated, } \\
\text { many associations made } \\
\text { among concepts, allows for } \\
\text { understanding and reflection) } \\
\text { (Weimer, 2002). }\end{array}$ & $\begin{array}{l}\text { Students often learn through } \\
\text { memorization, and they may } \\
\text { not create meaning from the } \\
\text { material learned. }\end{array}$ \\
\hline $\begin{array}{l}\text { Why evaluate students? } \\
\text { Evaluation promotes learning } \\
\text { and improvement and provides } \\
\text { feedback and results in } \\
\text { competency decisions about } \\
\text { students WWeimer, 2002). }\end{array}$ & $\begin{array}{l}\text { Evaluation is separate from } \\
\text { learning and is used to provide } \\
\text { feedback and make grade } \\
\text { distinctions among the students. }\end{array}$ \\
\hline $\begin{array}{l}\text { Can all students succeed? } \\
\text { well-being and success of all } \\
\text { students and adapt teaching } \\
\text { and learning transactions to } \\
\text { accommodate for individual } \\
\text { differences (Barr \& Tagg, } \\
1995) .\end{array}$ & $\begin{array}{l}\text { Accepts idea that some students } \\
\text { will fail or do not as well as } \\
\text { others often because grading } \\
\text { falls along a bell-shaped curve }\end{array}$ \\
\hline
\end{tabular}

\section{Notes}

- If a characteristic or indicator is not referenced it is because this idea can be found in most of this literature on learning-centered teaching.

- Key concepts are in italics.

- From: Blumberg, P. (2004). Beginning journey toward a culture of learning-centered teaching. Journal of Student-Centered Learning, 2(1), 69-80. 
Key Outcome Indicators

\begin{tabular}{|c|c|c|}
\hline Outcome domains & $\begin{array}{l}\text { Desirable outcome indicators } \\
\text { that should occur with } \\
\text { learning-centered teaching }\end{array}$ & $\begin{array}{l}\text { Unsatisfactory outcome } \\
\text { indicators }\end{array}$ \\
\hline $\begin{array}{l}\text { Who is responsible for } \\
\text { learning to occur? }\end{array}$ & $\begin{array}{l}\text { Students take responsibility for } \\
\text { their own learning. }\end{array}$ & $\begin{array}{l}\text { Faculty define what and how } \\
\text { learning should occur. }\end{array}$ \\
\hline $\begin{array}{l}\text { What roles do assessments } \\
\text { play in courses? }\end{array}$ & $\begin{array}{l}\text { Assessment is part of the } \\
\text { learning process with students } \\
\text { engaged in self and peer } \\
\text { assessment, faculty giving } \\
\text { constructive feedback on how to } \\
\text { improve (Weimer, 2002), and } \\
\text { providing information to assign } \\
\text { srudent grades. }\end{array}$ & $\begin{array}{l}\text { Assessment provides information } \\
\text { so assign studens grades; may be } \\
\text { seen as taking away time from } \\
\text { teaching content. }\end{array}$ \\
\hline What is assessed? & $\begin{array}{l}\text { Fundamental knowledge, } \\
\text { skills, critical thinking, } \\
\text { integration, values, learning } \\
\text { how to learn (Fink, 2003) }\end{array}$ & $\begin{array}{l}\text { May evaluate rote or surface } \\
\text { learning of content at the } \\
\text { expense of other objectives }\end{array}$ \\
\hline \multirow[t]{2}{*}{$\begin{array}{l}\text { What can students do } \\
\text { with acquired knowledge? }\end{array}$} & $\begin{array}{l}\text { Students are inquisitive } \\
\text { explainers (Graesser et al., } \\
\text { 2002). }\end{array}$ & $\begin{array}{l}\text { Students are fact collectors } \\
\text { (Graesser et al., 2002). }\end{array}$ \\
\hline & $\begin{array}{l}\text { Students are active users of } \\
\text { knowledge (Graesser er al., } \\
\text { 2002); knowledge is used to } \\
\text { develop learning skills } \\
\text { (Weimer, 2002). }\end{array}$ & $\begin{array}{l}\text { Students are repositories of } \\
\text { inert knowledge (Graesser et al., } \\
\text { 2002). }\end{array}$ \\
\hline $\begin{array}{l}\text { How are students } \\
\text { evaluated? }\end{array}$ & $\begin{array}{l}\text { Multiple assessment methods } \\
\text { should emphasize forward } \\
\text { assessment (tests on ability to } \\
\text { use what was covered in the } \\
\text { class in a new way, career } \\
\text { applications) (Fink, 2003). }\end{array}$ & $\begin{array}{l}\text { Evaluation often emphasizes } \\
\text { backward assessments (covers } \\
\text { mostly what was covered in the } \\
\text { class) (Fink, 2003). }\end{array}$ \\
\hline Who should assess students? & $\begin{array}{l}\text { Self, peer, facults } \\
\text { professionallpractitioner } \\
\text { assessments }\end{array}$ & Faculy \\
\hline $\begin{array}{l}\text { Is shere an end point to this } \\
\text { learning? }\end{array}$ & $\begin{array}{l}\text { Students become self-directed. } \\
\text { lifelong learners. }\end{array}$ & $\begin{array}{l}\text { Learning about a discipline ends } \\
\text { when the course is over }\end{array}$ \\
\hline
\end{tabular}

\section{Notes}

- If a characteristic or indicator is not referenced it is because this idea can be found in most of this literature on learning-centered teaching.

- Key concepts are in italics.

- From: Blumberg, P. (2004). Beginning journey toward a culture of learning-centered teaching. Journal of Student-Centered Learning, 2(1), 69-80. 